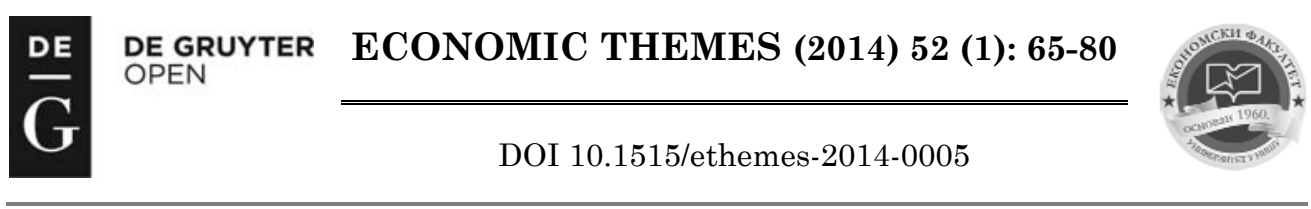

\title{
HOW TO APPLY THE SUSTAINABILITY BALANCED SCORECARD CONCEPT
}

\author{
Bojan Krstić
}

University of Niš, Faculty of Economics, Serbia

$\bowtie$ bojan.krstic@eknfak.ni.ac.rs

\section{Vesna Sekulić}

University of Niš, Faculty of Economics, Serbia

$\bowtie$ vesna.sekulic@eknfak.ni.ac.rs

\section{Vladimir Ivanović}

PhD student, University of Niš, Faculty of Economics, Serbia $\bowtie$ vladimir.makicar@gmail.com

UDC

005:502.131.1

Original

scientific

paper

Received:

08.12.2013

Accepted:

02.04.2014

\begin{abstract}
Many successful enterprises have identified a large significance of non-economic determinants of business and their influence on competitive success. Social responsible behaviour becomes an imperative of modern business environment. Corporate social responsibility emphasizes more effective environmental and social performance management so that its influence on financial performance becomes more and more obvious. In that sense, the aim of this paper is to point out the theoretical foundations of the Sustainability Balanced Scorecard (SBS) concept, and to demonstrate an example of enterprise, which will show how to develop SBS in the aim of its successful application.
\end{abstract}

Keywords: environmental performance, social performance, sustainable development, enterprise.

\section{Introduction}

For a long time, many enterprises have not been paying enough attention to environmental and social dimension of their business activities, although these dimensions significantly influence economic transactions and market position. Concerning important environmental and social components of business activities, managers need new or existing, but innovated managerial tools to 
emphasize corporate social responsibility and sustainable development of their enterprises. Taking into account these facts, the authors such as Nicolau et al. (2005), Bieker (2003), Figge et al. (2002a) suggest improving the Balanced Scorecard (BS) concept with environmental and social dimensions which reflect sustainable development of enterprise. The Sustainability Balanced Scorecard $(S B S)$ is complementary with environmental management systems, which had been used by numerous companies before the concept appeared (EMS, ISO 14000, EMAS, SA 8000). However, these systems have usually been applied for a short time from several reasons (Nicolau et al, 2005). Firstly, they could be applied at the operational level and they are not connected with strategic planning and strategic management of the enterprise. Secondly, they have been implemented separately from traditional management systems that middle and top management use in directing and controlling business activities. These two problems intrigued Kaplan and Norton $(1992,1997,2004,2001,1996)$ to search for possibilities to improve the Balanced Scorecard in the direction of creating the so-called Sustainability Balanced Scorecard. Apart from the existing financial and non-financial dimension of business performance, the new concept separately includes environmental and social dimension. In that way, SBS provides a broader managerial perspective and incorporates some missing dimensions of business activities of a modern enterprise. As a performance management tool, the Balanced Scorecard has been improved by adding some new aspects of business activity which are necessary for effective and efficient decision-making by the top management (strategic domain), as well as by the middle and operational management (operational domain). Incorporating these dimensions is important for all management levels as well as for connecting strategic and operational management perspectives.

Conceptually, the problem of sustainable development management, in the context of applying the SBS model, is concentrated on identifying the key determinants or success factors of sustainable development that managers have to manage by their measuring, monitoring, controlling and improving. Namely, aside rom the economic (profit focused) goals of enterprise stakeholders, management should also define the non-economic social goals and incorporate them into an integral system of goals. The sustainable development of an enterprise implies economic (financial) dimension, but also respects the requirements of corporate social responsibility domain (Hsu, Liu, 2009). It is necessary to improve business performance in all three dimensions of sustainable development - economic, environmental and social - at the same time. (Figge et al., 2002a, p. 272) 


\section{Different Approaches to Integrating Social Responsibility and Sustainable Development Aspects into the Sustainability Balanced Scorecard}

The Sustainability Balanced Scorecard (SBS) concept gets a new content in terms of managing and controlling dimensions (perspectives), and also a new architecture compared to the classical Balanced Scorecard concept (Figge et al., 2002a). Nicolau et al. (2005) present the SBS model through the following phases: 1 . Scanning the current market position and business performance of the enterprise, 2. Formulating vision, mission and system of the fundamental values of the enterprise, 3. Defining the enterprise's strategic goals and their structuring through four perspectives of the Balanced Scorecard (financial, customer, internal processes, learning and growth), 4. Integrating these economic perspectives into the direction of enterprise's sustainable development and adding environmental and social dimensions, 5. Identifying performance measurement system for three directions of the enterprise's sustainable development: economic, environmental, and social.

There are different approaches to the integrating aspects of corporate social responsibility and sustainable development. Figge et al. (2002a, 2002b) suggest three possible approaches for incorporating environmental and social dimensions of the enterprise's sustainable development into the Balanced Scorecard, which give it the character of the Sustainability Balanced Scorecard. The approaches are the following: 1. Integrating environmental and social aspect into the Balanced Scorecard with four initial perspectives that model suggests, so that key success factors (performance drivers) and performance indicators can be added by using top-down approach for introducing the environmental and social aspects; 2. Introducing additional, the fifth perspective into the Balanced Scorecard, which could be called an environmental or social perspective - the perspective of corporate social responsibility and sustainable development; 3 . The so-called deductive approach, which derives a specific addition from the basic Balanced Scorecard, that emphasizes environmental or social dimension, through the scorecard of environmental performance and/or scorecard of social performance. It is important to emphasize the assumption that the derived environmental or social scorecard cannot be created parallel with the scorecard according to the original Kaplan and Norton BS concept. The essence is that the derived environmental, social scorecard is an expansion of the previous two concepts. Operationally, the simplest approach is to introduce the additional, fifth perspective into the Balanced Scorecard.

The essence of the process of conceptualizing SBS is the same as with the traditional Balanced Scorecard. Firstly, the process of SBS formulation assumes the strategic analysis of resources (capabilities) and external environment, according to which enterprise should define its vision, mission, and 
fundamental organizational values. According to this, the defined vision is differentiated from the aspect of stakeholders and processes, which includes: 1 . Owners, 2. Customers, 3. Internal processes (operational processes - resource supply, customer management, innovative processes), 4. Learning and growth (employee improvement and development, creativity and innovativeness improvement), 5. Local community. The SBS concept emphasizes the local community as a stakeholder group, as well as relationships with the actors in the community. Namely, it emphasizes social responsibility and sustainable development. It means that instead of four existing perspectives, the new concept has five performance perspectives. The fifth, additional perspective is non-economic and it is called the perspective of corporate social responsibility or sustainable development of enterprise (Krstić, 2012).

Operationalization of the process of applying the SBS concept assumes several steps or phases. The order of the relevant phases in developing SBS is as follows (Krstić, 2012): 1. Defining mission, vision and strategy of the enterprise or its business units; 2. Creating the sustainable development strategy of the enterprise and/or incorporating elements of the sustainable development strategy into corporate or business strategy; 3. Identifying environmental and social exposure of the enterprise which means analysing the strategic relevance of social responsibility and sustainable development dimensions and determining the key perspectives (dimensions) within SBS; 4. Identifying the key success factors, especially the factors connected to environmental and social component of enterprise's sustainable development, that is, the factors which determine success in realizing the corporate and business strategy of sustainable development; 5. Identifying the key performance indicators in each perspective for monitoring key success factors; 6. Identifying cause-effect relationships between the dimensions in SBS and illustrating graphically corporate or business strategy by strategic map; 7. Defining the target levels of chosen performance measures for future period (usually a year); 8 . Implementing the model through identification of actions, programs, activities which will help to achieve the defined operational goals. Also, there is the need to identify and plan the activities related to corporate social responsibility, that is, to environmental and social dimension of enterprise's sustainable development. In order to realize the implementation process efficiently, each step has to be realized adequately, so it is relevant to explain their essence.

\section{Identifying the Relevancy of Environmental and Social Dimension for Enterprise's Business Activity - The Essential Issue of the Sustainability Balanced Scorecard Concept}

The sustainable development goals of an enterprise are mostly related to its employees, so their determination should results from the vivid discussion in which participants express their expectations or give suggestions, solutions or 
directions for realization. Therefore, once defined strategy has to be periodically modified or even radically redefined in order to provide the expected growth/development of an enterprise and its sustainable development goal realization (Krstić et al., 2008, Lambert et al., 2012, Hansen, Schaltegger, 2012). This is particularly important in situations when strategic importance of environmental and social aspects is not properly assessed.

Identifying environmental and social exposure, both at the corporate and business unit level, is a necessary step in observing the viability of the SBS concept application in an enterprise. In that sense, the so-called environmental and social exposure profile has to be identified (Figge et al., 2002a, 2002b). Identification of environmental exposure of an enterprise or business unit is necessary to determine the specific activities (initiatives, actions, projects, programs) for an enterprise/business unit, according to environmental intervention types (emissions into the air, water, soil, waste, noise, lost thermal energy, materials/raw-materials, radiation, etc.) (Figge et al., 2002a). Strategic relevant social aspects can be identified analogous to the environmental aspects. However, it is very hard to give their all-inclusive classification. It is pointed out, however, that the social aspect mostly depends on preferences and values of different actors who exist in the business scene, so it is advisable to classify social factors according to actors/stakeholders involved. The stakeholder approach provides a useful basis for classifying the actors who have different social requirements. Regarding each stakeholder or stakeholder group some important requirements, problems or questions should be defined. Therefore, all relevant stakeholder groups have been firstly identified and then their social requirements and questions have to be determined.

Determining strategically relevant aspects or areas is the key step both in original BS and in new, expanded the SBS concept. The primary purpose of establishing this kind of step is translating the formulated strategy into the cause-effect goals and indicators. In order to better understand appropriateness of the concept, it is necessary to repeat Kaplan and Norton's recommendation (1992) that the process of identifying strategically relevant aspects should be realized on the top-down principle, which means that the all main initiatives, suggestions and solutions start from the top management. Of course, the same approach which is valid for the original Balanced Scorecard concept can also be valid for SBS concept. The only difference is in taking into consideration environmental and social perspective together with basic perspectives recommended by Kaplan and Norton (Figge et al., 2002b).

Environmental and social components can represent the strategic or key success factors, and control their influence means creating and applying an adequate set of performance indicators. These are the social responsibility and sustainable development performance indicators, and their role is to measure whether strategic and essential requirements are achieved within the frame of 
sustainability development perspective. This set of social responsibility and sustainable development performance indicators represents a supplement to the Balanced Scorecard as a performance measurement system with the indicators which cover four basic perspectives in the Kaplan and Norton's model. Otherwise, indicators of corporate social responsibility and sustainable development of an enterprise which can be used are numerous ${ }^{1}$, but their selection is being performed respecting the criteria of consistency, criteria of possible information providing for their measuring, and criteria of necessary infrastructure for measuring (information, software, and stuff). Selection of the key environmental performance indicators becomes more important in a globalized business environment, since modern enterprises face the growing environmental challenges (Tsai et al. 2009). Firstly, there are laws which force enterprises to take responsibility for their environmental actions which, consequently, requires from enterprises to constantly measure and monitor their environmental performances. ${ }^{2}$ Considering their significance, the indicators help managers in the process of strategic decision-making and in observing their influence on the whole business performance (Klassen, McLaughlin, 1996).

\section{Illustration of SBS Application - A Case Study}

"FRU" is the enterprise in the business of fresh fruit processing by freezing and drying. It dries plums, and freezes cherry, blackberry, and strawberry. The drying process is being performed in specially made drying kilns, and freezing in the refrigerator. The enterprise is working in an economically undeveloped region, and gets raw-materials from the local producers (by direct purchase of fresh fruit). The enterprise sees itself as a successful fruit manufacturer in the market where the target group (dairies, confectionery industry) shows demand for "FRU" products, but also requires their high quality, followed by appropriate certificates (ISO, HACCP). The research that the enterprise undertook showed that target market requires the fruit with higher quality which actually means higher devotion to health and safety characteristics and other

\footnotetext{
${ }^{1}$ For example: Percentage of enterprise's suppliers (from their total number in the last three years) which are not marked as polluters, Number of products from the assortment which can be recycled, Indicators of product waste quality change, Quality changes in air, water, as well as emission of other pollution comparing to the previous year, Non-discrimination on the work, work certainty, Indicators of the working process human aspect, Contribution of enterprise to local employment, Value of charity donations, Annual average number of training hours for health and safety, Number of incidents and injuries during the work, Number of positive stories and reviews in media about enterprise ethical behaviour, as well as ethical behaviour of its management structures, Number of cases of enterprise ethical code disrespect by managers and non-management stuff, etc.

${ }^{2}$ The significance of environmental performance measures confirms a fact that International Organization for Standardization (ISO) devoted a special standard for them - ISO 14031: standard about environmental performance valuation.
} 
quality features. This is particularly important considering the fact that the part of frozen products are sold to the diaries which produce fruit yogurts. The environmental and social components have not found their place in the enterprise's business strategy up to now. On the other hand, buyers usually do not want to pay more for higher quality, so "FRU" is forced to create serious quality improvement and keep the price at the same level as long as possible. According to the stated facts, the new vision and strategy basis of top management could be shown as follows: produce and sell high quality and long-lasting fruit at competitive prices for the buyers with expressed needs for healthy and safe products. To implement this strategy, it is very useful to use the Balanced The Scorecard concept expanded with environmental and social components of the business (Krstić, Ivanović, 2010, 2012).

\subsection{Business Performance Perspectives of the Enterprise "FRU"}

Financial perspective consists of financial indicators. Apart from main financial measures (shareholder value, economic value added, return on invested capital), sales volume and expenses are usually seen as the most important indicators within financial perspective. The specific environmental and social indicators are not usually found within financial perspective. As an example for financial measures the increasing net-margin from 3\% to $5 \%$ within 3 years can be point out, which will be realized by increasing turnover for $25 \%$ and by increasing return on sales of $5 \%$ to $6.5 \%$.

Customer perspective is turned towards consumers or buyers of the enterprise's products. In this perspective, the focus is on a target group of consumers that will get the significant attention, efforts and resources because it is expected from the group to give the highest contributions to financial results. If the enterprise "FRU" decides to increase sales for $25 \%$, when defining its financial perspective, it could be done by raising the ratio of market share from $15 \%$ to $20 \%$ in the target customer segment. The management is convinced that the appropriate sales improvement programs will bring the expected performance levels. The factor with great influence on consumer satisfaction is quality, which in this context has strategic importance for achieving the goal of sales increase.

Leading performance indicators of the enterprise are referred to the planned way for achieving target market success. The market analysis indicated that healthy and safe products were the most important aspect in customer perspective of this enterprise. As the consequence, there is an influence of health institutions and hygienic institutes as a specific interest group which task is to put on the market only foods which satisfy the strict health, microbiological and other standards. Also, regarding such product characteristics, there is a certain dose of pressure by consumer associations and 
non-governmental organizations whose presence is considered as strategically important. Therefore, the management of "FRU" is trying to create the environmentally and socially responsible enterprise. Of course, customer perspective is just a part of the puzzle of efforts towards stable and optimal business performance in the context of modern efforts to environmentally and socially responsible behaviour of enterprises. Its implications can be shown in Figure 1.

Figure 1 Customer Perspective in the Eenterprise "FRU"

\begin{tabular}{|c|c|c|c|c|c|c|c|c|c|}
\hline & \multirow{2}{*}{\multicolumn{4}{|c|}{ Environmental exposure }} & \multicolumn{4}{|c|}{ Social exposure } \\
\hline & & & & & & \multicolumn{2}{|c|}{$\begin{array}{c}\text { Direct } \\
\text { stakeholders }\end{array}$} & \multicolumn{2}{|c|}{\begin{tabular}{|c|c|}
$\begin{array}{c}\text { Indirect } \\
\text { stakeholders }\end{array}$ \\
\end{tabular}} \\
\hline & & 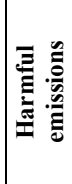 & 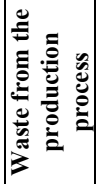 & 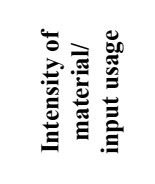 & 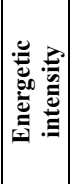 & 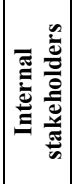 & 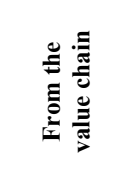 & 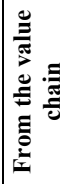 & 产 \\
\hline \multirow{2}{*}{ 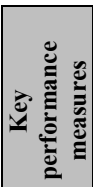 } & $\begin{array}{c}\text { Market share } \\
\text { Goal: from } 15 \% \text { to } \\
20 \% \\
\end{array}$ & & & & & & & & \\
\hline & $\begin{array}{l}\text { Consumer } \\
\text { satisfaction }\end{array}$ & & & & & & Consumers & & \\
\hline \multirow{3}{*}{ 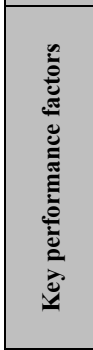 } & $\begin{array}{c}\text { Product features } \\
\text { Long-lasting } \\
\text { products } \\
\text { Products which do } \\
\text { not contain harmful } \\
\text { substances }\end{array}$ & & & $\begin{array}{c}\text { Pesticide } \\
\text { contamination }\end{array}$ & & & Consumers & & $\begin{array}{l}\text { Health } \\
\text { institutions } \\
\text { Hygienic } \\
\text { institute }\end{array}$ \\
\hline & $\begin{array}{c}\text { Consumer relationships } \\
\text { and image }\end{array}$ & & & & & & & & \\
\hline & $\begin{array}{c}\text { Image of } \\
\text { environmentally and } \\
\text { socially responsible } \\
\text { enterprise }\end{array}$ & & & & & & Consumers & & \\
\hline
\end{tabular}

Internal process perspective is especially important since it assumes to identify the processes which are essentially relevant for achieving goals in the customer and financial perspective. For that purpose, it is necessary to define how goals of the two mentioned perspectives will be achieved and how necessary relationships among these two perspectives and internal process perspective will be created. The key performance indicators (Figure 2) within the frames of this perspective can be presented in three partial processes innovations, operations (production) and customer services. Indicators within these processes can be further divided into indicators that concern expenses, time, and quality. In the internal process perspective, key performance factors in this enterprise are raw-materials purchase quality control, usage of harmful substances in the production and efficiency in energy, water and material usage in the processes. 
Figure 2 Internal Process Perspectives in the Eenterprise "FRU"

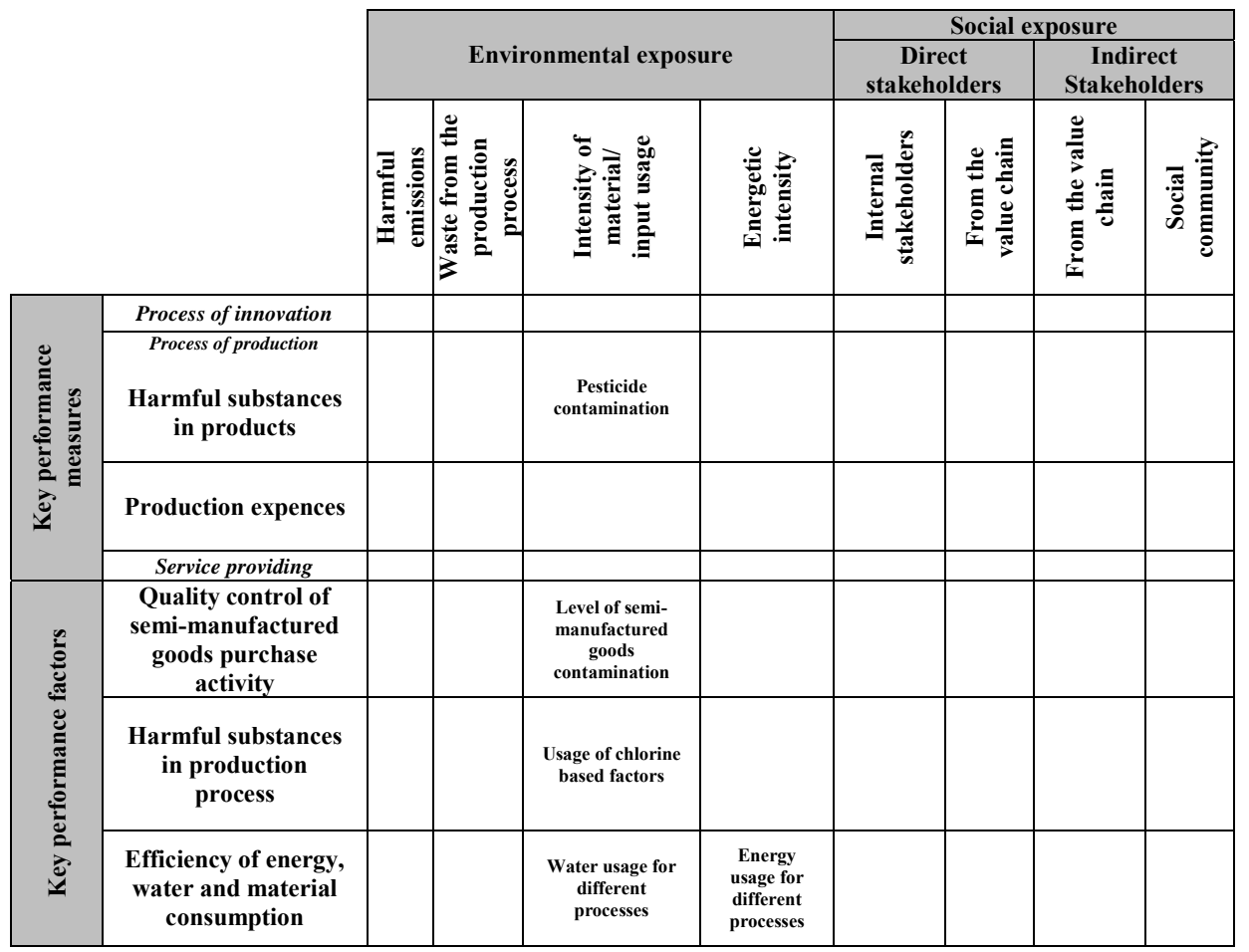

Learning and growth perspective, in the simplest words, describes the infrastructure necessary to achieve goals of the other business perspectives. The most important areas within this perspective are employee qualification and motivation, as well as their orientation towards goal achieving. Like in all other perspectives, goals and indicators are causally interconnected with the higher level perspectives in order to demonstrate how strategically relevant aspects of learning and growth perspective contribute to successful strategy implementation. Successful strategy implementation of the enterprise "FRU" is conditioned by key assumption of highly motivated and satisfied employees, so it could be concluded that employee satisfaction is the most important key performance indicator in the learning and growth perspective (Figure 3).

The management of the "FRU", like management of every other enterprise, believes that positive work climate and atmosphere are essential in gaining high employee satisfaction. In that context, air quality in working places plays an important role. So, the working technology specificity could influence employees to be mostly exposed to high air temperature (because of the drying kilns), as well as to low temperature (because of the freezing). Also, the basic cooling fluid for freezing is Freon, which potential leakage could endanger employees' health and cause air pollution. 
Slika 3: Perspektiva učenja i rasta u preduzeću „FRU”

\begin{tabular}{|c|c|c|c|c|c|c|c|c|c|}
\hline & \multirow{2}{*}{\multicolumn{4}{|c|}{ Ekološka izloženost }} & \multicolumn{4}{|c|}{ Socijalna izloženost } \\
\hline & & & & & & \multicolumn{2}{|c|}{$\begin{array}{c}\text { Direktni } \\
\text { stejkholderi }\end{array}$} & \multicolumn{2}{|c|}{$\begin{array}{l}\text { Indirektni } \\
\text { stejkholderi }\end{array}$} \\
\hline & & 总 & 苞 & 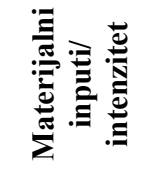 & 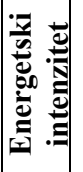 & 飽 & 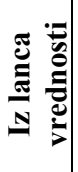 & 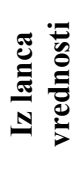 & 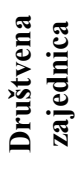 \\
\hline 즐 & $\begin{array}{c}\text { Satisfakcija } \\
\text { zaposlenih }\end{array}$ & & & & & Zaposleni & & & \\
\hline \multirow{3}{*}{ 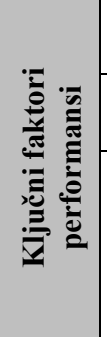 } & $\begin{array}{l}\text { Potencijali } \\
\text { zaposlenih }\end{array}$ & & & & & & & & \\
\hline & $\begin{array}{l}\text { Fluktuacija } \\
\text { zaposlenih }\end{array}$ & & & & & & & & \\
\hline & $\begin{array}{c}\text { Radna } \\
\text { atmosfera } \\
\text { Zdravlje i } \\
\text { bezbednost } \\
\text { zaposlenih }\end{array}$ & $\begin{array}{c}\text { Emisije } \\
\text { previše } \\
\text { toplog ili } \\
\text { hladnog } \\
\text { vazduha }\end{array}$ & & $\begin{array}{l}\text { Korišćenje } \\
\text { freona }\end{array}$ & & & & & \\
\hline
\end{tabular}

\subsection{Non-Economic Performance Perspective of the Enterprise "FRU"}

Successful strategy realization of the enterprise "FRU" can be influenced significantly by the strategically relevant environmental and social aspects with some mechanisms different from the market, so there is a need to check whether they really exist. The decision about introducing this additional perspective can be brought by answering some questions which follow.

Are there any environmental and social aspects that influence the success of enterprise "FRU"?

The answer to this question can be looked in the matrices in Figure 4. It shows the relevant environmental and social aspects with two categories of potential strategic essential aspects of the so-called non-economic perspective. The first category is legality and it assumes compatibility with environmental and social regulations and law requirements. It means that fruit producers fulfilled all the conditions for work required by the law. Within the second category, there is organizational legitimacy. However, in the direct fruit production, the vast number of employees is people with low education and knowledge about the significance of compliance with strict procedures from the quality standards which provide healthy and safe products. Because of that, fruit producers are the subject of interest for different social groups (buyers, non- 
governmental organizations, sanitary inspectorate, etc.), which have interest to assure products with high quality.

Figure 4 Non-Economic Perspective in the Enterprise "FRU"

\begin{tabular}{|c|c|c|c|c|c|c|c|c|c|}
\hline & \multirow{2}{*}{\multicolumn{4}{|c|}{ Environmental exposure }} & \multicolumn{4}{|c|}{$\begin{array}{l}\text { Social exposure } \\
\end{array}$} \\
\hline & & & & & & \multicolumn{2}{|c|}{$\begin{array}{c}\text { Direct } \\
\text { stakeholders }\end{array}$} & \multicolumn{2}{|c|}{$\begin{array}{c}\text { Indirect } \\
\text { stakeholders }\end{array}$} \\
\hline & & 号参 & 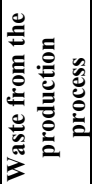 & 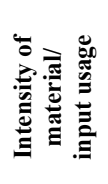 & 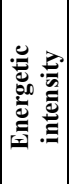 & 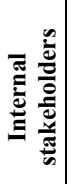 & 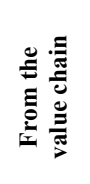 & 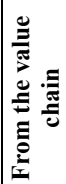 & 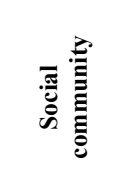 \\
\hline \multirow{2}{*}{ 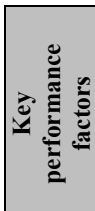 } & $\begin{array}{c}\text { Aspect of legitimacy } \\
\text { Education and expertise } \\
\text { of fruit producers }\end{array}$ & & & & & & Buyers & & NGO's \\
\hline & $\begin{array}{c}\text { Aspect of legality } \\
\text { Education and expertise } \\
\text { of fruit producers }\end{array}$ & & & & & & & & $\begin{array}{c}\text { Health } \\
\text { institutions } \\
\text { Hygienic } \\
\text { institute }\end{array}$ \\
\hline
\end{tabular}

Do these environmental and social aspects represent the strategic essential issues that "FRU" should respond to in order to implement the strategy successfully?

Introduction of non-economic perspective is justifiable in the situation when environmental/social aspects represent the strategic issues. In that sense, the two theoretical approaches are taken into consideration. In the first theoretical approach, introducing the environmental/social perspective in SBS serves to show how serious the strategic success consequences would be if the requirements of this non-economic perspective are not fulfilled. The stronger and more serious these consequences are, the more significant are the appropriate environmental and social (non-economic) aspects. On the other hand, the enterprise has to separate strategically important issues from other factors and issues. Finally, the non-economic perspective should be introduced for taking into consideration some essential aspects from the enterprise's environment.

What is the most important contribution of the non-economic aspect in realizing strategy of the "FRU"?

Figure 4 shows that the social exposure of the fruit producers is the key noneconomic factor of the "FRU's" success. Such exposure is the consequence of the fact that suppliers of the enterprise come from undeveloped areas, with low levels of education and expertise about fruit production and it could imply the risks of using too much chemicals, harmful for people's health. Fruit which contains that kind of substances is not healthy for further processing because it can endanger all other participants in the value chain. Non-governmental 
organizations make public and open pressure in order to ban usage of certain (very hazardous) pesticides, and also to significantly decrease usage of others. The sanitary inspectorate controls quality of the fruit produced and requires constant sample control. And, finally, the frozen and dried fruit producers want to know which fruit quality is going to enter their final products (which brings them a profit). Because of that, "FRU" has identified its socially responsible image as a core strategic issue in a customer perspective. This strategic goal will be achieved only if "FRU" proves that its suppliers and other contractors do not use prohibited chemicals, too harmful for people and the environment. The strong public outcry about this sensitive issue could destroy the competitive advantage of the socially responsible image. On the other hand, if "FRU" could manage to position itself as a credible market actor, which does not cooperate with suppliers who use harmful chemicals in fruit production, it could create the competitive advantage. Lagging indicator in non-economic perspective is tightly connected with customer perspective. However, the most important key performance factor for avoiding harmful substances in production can be found in process perspective, considering the fact that "FRU" has gained social routine in its activities of purchase quality control.

\subsection{Strategic Map of enterprise "FRU" based on SBS}

The last two steps in SBS concept implementation - defining goals and measures and implementing into the management system are clarified and analysed through detailed presentation of perspectives within SBS concept and the "FRU" strategic map. When analysing SBS perspectives, it is important to point out that the identified causal relationship between strategically relevant aspects do not exist only between leading and lagging indicators within one perspective. All the aspects and indicators would have to be directly or indirectly connected with financial perspective. Strategic essential aspects of the lower perspective levels serve to achieve set of goals that are given by indicators of higher level perspective. Every time when shifting from the higher level to the first lower level (cascade principle), it must be assured and explicitly shown how those lower levels of key success factors and key performance indicators will contribute to goal achieving in higher level perspectives. This is the way for possibility to create a hierarchical "causeeffect" chain which connects all strategically relevant aspects towards successful strategy execution. According to defined process, it follows that all strategically relevant aspects are presented with appropriate leading or lagging performance indicators and they are the part of the cause-effect network which visualizes and translates goals into concrete actions (Johnson, 1998). Shifting through the perspectives, following top-down principle, the strategic relevance of environmental and social aspects is determined, as well as for all other traditional aspects of the enterprise's Balanced Scorecard. This ensures 
complete and value-oriented integration of the environmental and social component in the total management system of an enterprise.

The result of SBS formulation process can be graphically presented by using the strategic map. Such a map shows all economic, environmental and social aspects, identified like strategically relevant ones and presented in a hierarchical network of the "cause-effect" chain. When the strategically relevant aspects are identified and harmonized, the next step is defining goals and indicators for controlling and managing business performance in the direction of long-term success and high contribution to the enterprise's sustainable development.

Figure 5 Strategic Map of the Eenterprise "FRU"

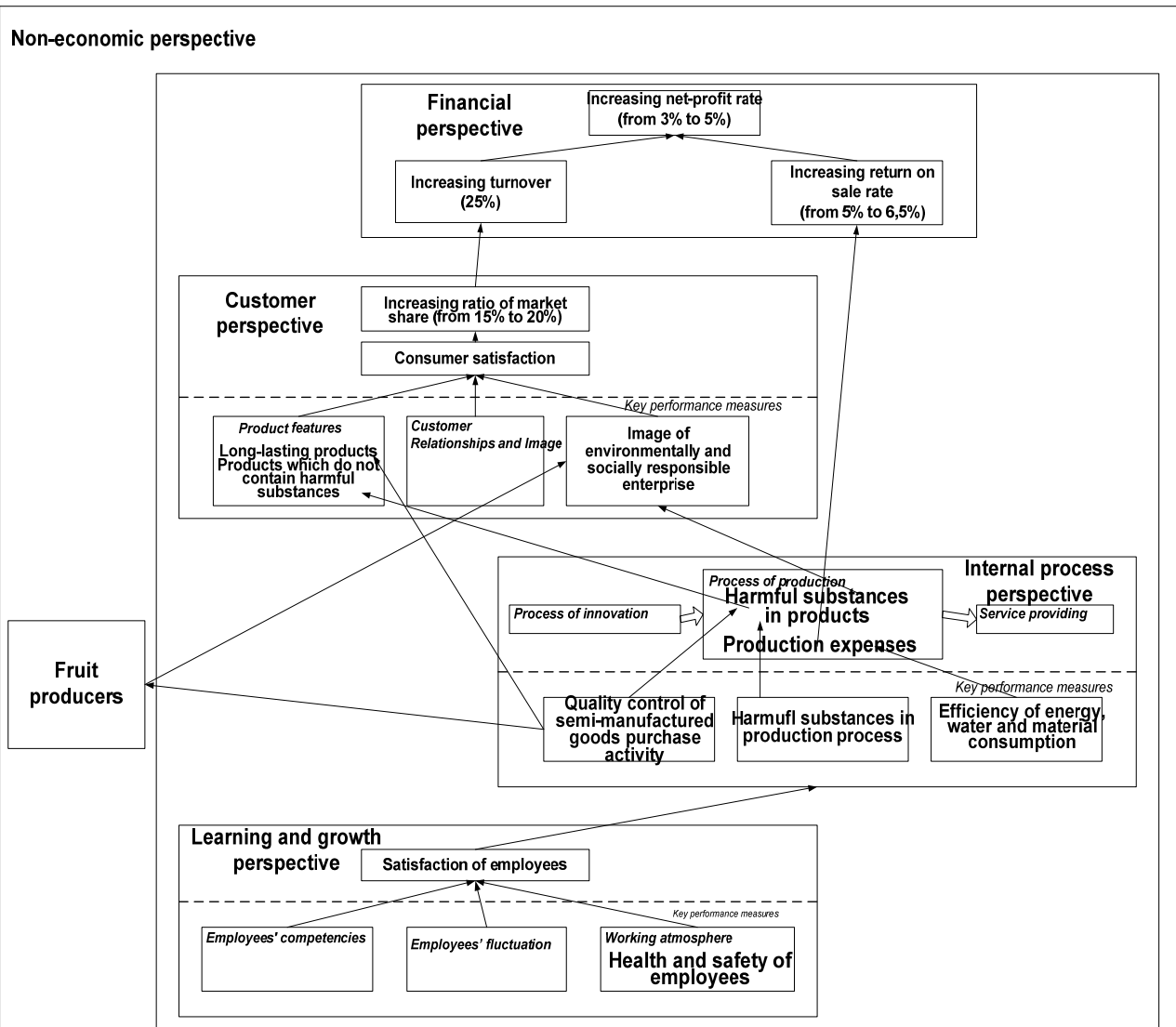

Figure 5 presents the strategic map of the enterprise "FRU" which, in order to improve net-margin rate for $5 \%$, wants to increase its turnover for $25 \%$ by increasing its market share from $15 \%$ to $20 \%$. In achieving these ambitious goals, "FRU" will be successful only if it directs its products more towards 
customer's requirements. In order to get closer to the customers, it is necessary to form the adequate marketing strategy, whose essence will be based on "green" products or products which do not contain harmful substances and building the image of environmentally and socially responsible enterprise. Consequently, lowering harmful substances in products is one of the central goals of a process perspective. This will be achieved by the purchase of "green" raw-materials and using environmentally friendly and safe for human health substances as input in production. Of course, in providing less harmful rawmaterials, purchase department must control and take care that value-chain does not include fruit producers, who do not pay attention to quality standards and use prohibited chemical substances in fruit growing. At the same time, "FRU" wants to achieve the setting financial goals by increasing sale margin from $5 \%$ to $6.5 \%$, which will be done by decreasing expenses through more efficient usage of energy, water and materials. "FRU" knows very well that successful implementation and execution of its ambitious strategy requires highly motivated and satisfied employees.

\section{Conclusion}

Incorporating sustainable development components into the Kaplan and Norton's Balanced Scorecard, as a process through which organization manages performance and generates value, becomes imperative of business activities of modern enterprises. Conceptualizing new, theoretically consistent and practically applicable model of SBS in modern "knowledge economy" requires defining, measuring, improving, valuating, and managing sustainable development performance.

Generally, the fifth (non-economic) perspective in the Balanced Scorecard can be marked as a socially responsible and sustainable development perspective. It is directed to requirements and interests of social community as a specific stakeholder of an enterprise. This perspective should cover environmental and social aspect of sustainable development, that is, emphasize aspiration of modern enterprises to enlarge social responsibility and sustainable development. Improvement of the concept is in the function of efficient business performance management in the sense of managing economic and noneconomic business success factors. Economic determinants of business activities are covered within business perspectives in the original Balanced Scorecard concept (financial, customer, process, etc.). Non-economic determinants of business activities (socially responsible business) can be covered by including environmental and social dimensions of sustainable development.

Theoretical determination of the methodological framework of SBS (perspectives, approaches, performance indicators) is challenging requirement 
for managers who have increasing demands for social responsibility in todays modern business world. The importance of the SBS concept can be best described by the fact that improvement of socially responsible and sustainable development performance could significantly influence the level of achieved business success and competitiveness of modern enterprise.

\section{References}

Bieker, T., (2003) "Sustainability management with the Balanced Scorecard", International Summer Academy on Technology Studies - Corporate Sustainability, pp. 1-17.

Bieker, T., Dyllick, T., Gminder, C-U., Hockerts, K (2001) "Towards the Sustainability Balanced Scorecard Linking Environmental and Social Sustainability to Business Strategy", Conference Proceedings of Business Strategy and the Environment, IWOe-HSG, University of St. Gallen

Cheng, C. Y., Fet, A. M., Holmen, E. (2010) "Using a Hexagonal Balanced Scorecard Approach to Integrate Corporate Sustainability into Strategy", $16^{\text {th }}$ International Sustainable Development Research Conference, Hong Kong: The Kadoorie Institute, The University of Hong Kong, pp. 1-17

Figge, F., Hahn, T., Schaltegger, S., Wagner, M., (2002a) "The Sustainability Balanced Scorecard - Linking Sustainability Management to Business Strategy", Business, Strategy and the Environment 11(5): 269-284.

Figge, F., Hahn, T., Schaltegger, S., Wagner, M., (2002b) "The Sustainability Balanced Scorecard - Theory and Application of a Tool for Value-Based Sustainability Management", $10^{\text {th }}$ International Conference of the Greening of Industry Network, Göteborg, Sweden.

Hansen, E. G., Schaltegger, S., (2012) "Pursuing Sustainability with the Balanced Scorecard: Between Shareholder Value and Multiple Goal Optimisation", Working Paper, Centre for Sustainability Management.

Henry, J. F., Journeault, M. (2008) "Environmental Performance Indicators: An empirical study of Canadian manufacturing firms", Journal of Environmental Management, 87: 165-176.

Hsu, Y.L., Liu, C.C., (2009) "Environmental performance evaluation and strategy management using balanced scorecard", Environmental Monitoring and Assesment, 170(1-4): 599-607.

Johnson, S.D., (1998) "Identification and selection of environmental performance indicators: Application of the balanced scorecard approach", Corporate Environmental Strategy, 5(4): 34-41.

Kaplan R., David N., (1996) Transalting Strategy into Action: The Balanced Scorecard, Boston Massachusets: Harvard Business School Press

Kaplan R., Norton D., (2001) The Strategy Focus Organization - How Balanced Scorecard Companies Thrive in the New Business Environment, Boston Massachusets: Harvard Business School Press

Kaplan R., Norton D., (2004) Strategy Maps - Converting Intangible Assets into Tangible Outcomes, Boston Massachusets: Harvard Business School Press 
Kaplan, R., Norton, D., (1992) "The Balanced Scorecard - Measures that Drive Performance", Harvard Business Review, January-February: 72-79.

Kaplan, R., Norton, D., (1997) Balanced Scorecard Strategien erfolgreich umsetzen, Stuttgart: Schäffer-Poeschel, p. 71.

Klassen, R.D., McLaughlin, C.P., (1996) "The Impact of Environmental Management on Firm Performance", Management Science, 42(8): 1199-1214.

Krstić B., Ivanović V., (2010) "Inkorporiranje dimenzija održivog razvoja u model Balansne karte performansi preduzeća", u Spasić D. i Stanković Lj. (eds.), The Challenges of Economic Science and Practice in the $21^{\text {st }}$ century, Niš: Ekonomski fakultet, 399-408.

Krstić, B., (2012) Uloga strategijske kontrole u unapređenju poslovnih performansi, Niš: Ekonomski fakultet.

Krstić, B., Ivanović, V., (2012) "Developing and implementing the SBS model with the aim of improving enterprise competitiveness", Facta Universitatis, 9(2): 177-192.

Krstić, B., Ivanović-Đukić, M., (2011) "Povezivanje ciljeva društvene odgovornosti sa strategijom za unapređenje konkurentnosti preduzeća", Nauka i svetska ekonomska kriza, Niš: Ekonomski fakultet, str. 269-279.

Krstić, B., Jovanović, S., Janković-Milić, V. (2008) "Sustainability Performance Management System of Tourism Enterprises", Facta Universitatis, 5(2): 123-131.

Lambert, S. C., Carter, A. J., Burritt, R. L., (2012) "Recognising Commitment to Sustainability through the Business Model", Working Paper No. 6, Centre for Accounting, Governance and Sustainability Occasional.

Nicolau, M, Teodorescu, M., Constantin, L., Teodorescu, C., (2005) "Balanced Scorecard and Sustainable Enterprise Strategy", Project title: Integrated Support for Sustainable Development of Chemical Industry Companies, through Implementation of EcoEfficiency Principles - INTEGR-IT

Thoresen, J. (1999) "Environmental performance evaluation - a tool for industrial improvement", Journal of Cleaner Production, 7: 365-370

Tsai, W.H., Chou, W.C., Hsu, W., (2009) "The sustainability balanced scorecard as a framework for selecting socially responsible investment: an effective MCDM model", Journal of the Operational Research Society, 60(10): 1396-1410

\section{KAKO PRIMENITI KONCEPT KARTE IZBALANSIRANIH PERFORMANSI ODRŽIVOG RAZVOJA}

Apstrakt: Mnoga uspešna preduzeća identifikovala su veliki značaj neekonomskih determinanti poslovanja i njihov uticaj na konkurentski uspeh. Društveno odgovorno poslovanje postaje imperativ savremenog poslovnog ambijenta. Društvena odgovornost preduzeća potencira sve efektivnije upravljanje njegovim ekološkim i socijalnim performansama čiji uticaj na finansijske performanse postaje sve evidentniji. U tom smislu, cilj ovog rada je da istakne teoretske postavke Karte izbalansiranih performansi održivog razvoja (Sustainability Balanced Scorecard), kao i da na primeru preduzeća pokaže na koji način se ona može razviti u cilju uspešne primene.

Keywords: environmental performance, social performance, sustainable development, enterprise. 